\title{
Two Series of Time in Logic, Natural Language, Computer Science and Artificial Intelligence $^{1}$
}

\author{
Dvě časové série v logice, přirozeném jazyce, informatice a umělé inteligenci
}

\author{
Zuzana Rybaříková \\ Nové technologie - výzkumné centrum \\ Západočeská univerzita v Plzni \\ Univerzitní 8, 30614 Plzeň \\ rybariko@ntc.zcu.cz
}

\begin{abstract}
Abstrakt/Abstract
J. M. E. McTaggart famously divided time into two time series, which he entitled A-series and B-series. Although he was proponent of neither of them, his division initiated a discussion as to which of the series is prior or real. This paper follows Clifford Williams's claim that these series are not as distant as their proponents argue they are. It demonstrates their translatability in the case of examples from temporal logic and natural language. It argues that, if there are any deep-rooted differences between these two series, they are only metaphysical. These metaphysical differences could be overcome by focusing on logic or natural language. These two series of time are also used in computer science and in the development of Artificial Intelligence. However, no attempt at unifying them has been suggested in these fields of study.
\end{abstract}

J. M. E. McTaggart rozdělil čas na dvě časové série, A-série a B-série. Třebaže nebyl zastáncem žádné z nich, jeho rozdělení podnítilo diskuzi, která z těchto časových sérií je přednější nebo jediná skutečně reálná. Tento článek navazuje na názor Clifforda Williamse, že tyto časové série nejsou tak rozdílné, jak tvrdí jejich zastánci. V článku je demonstrována jejich přeložitelnost na prríkladech z temporální logiky a přirozeného jazyka. Článek dále tvrdí, že jestliže je zde nějaký hluboce zakořeněný rozdíl mezi těmito dvěma sériemi, pak je pouze metafyzický. Tyto metafyzické rozdíly mohou být překonány, zaměříme-li se na logiku a přirozený jazyk. Tyto dvě časové série jsou také použity $\mathrm{v}$ informatice a rozvoji umělé inteligence, třebaže $v$ těchto oborech dosud nebyly navrženy žádné pokusy o jejich propojení.

${ }^{1}$ The research leading to these results has received funding from the Norwegian Financial Mechanism 2009-2014 and the Ministry of Education, Youth and Sports of the Czech Republic under Project Contract no. MSMT-28477/2014, Project no. 7F14236. 


\section{Introduction}

There is a notion of time flying, especially when one is having a good time. Time tends to be pictured like a river, which carries away all the past events. Yet, this concept of time is in contrast with the special theory of relativity. Nikolić stresses that certain features of the special theory of relativity violate the traditional concept of time. On the one hand, space and time were considered to be distinct entities. However, the special theory of relativity unites them into one entity entitled 'spacetime'. The picture of time as flowing turns to a picture of time as a block; the dynamic picture of time is replaced by the static one. One the other hand, the independence of past, present and future is questioned. According to the special theory of relativity, there is no such thing as an absolute present, and the notion of present is dependent on an observer's frame of reference. $^{2}$

Apart from the special theory of relativity, there is another line of argumentation, which focuses on the existence or non-existence of certain entities. It divides the philosophers of time into three groups with respect to their ontological views. Presentists argue that only present and present entities exist. Possibilists claim that both the past and present somehow exist and involve similar entities. Finally, eternalists hold the view that the past, present and future, as well as all of the entities in them, all exist in a certain way. In particular, presentists tend to accuse eternalists of positing an overpopulated universe. However, Callender criticised these approaches in philosophy. He claimed that this focus on existence was overcome in other branches of philosophy, while this is not the case in the philosophy of time. ${ }^{3}$

Following one part of Callender's critique, this paper does not aim to draw any metaphysical conclusions. This paper does not address what time really is. Philosophers are not the right people to make conclusive claims on this subject. In accordance with good analytic traditions, physicists are the appropriate experts in this field. Although Nikolić and Burgan point out a lack of agreement even among physicists, this is not the occasion for defending criticisms of the special theory of relativity. ${ }^{4}$

At the end of his paper, Callender suggests that the seemingly divergent theories of time could be unified, and that the metaphysical debate among eternalists, presentists and possibilists might not last until the end of time. ${ }^{5}$ Although the aim of this paper is not to finish this debate, but to present a particular unification of different concepts of time. The focus will not be on the metaphysical position, which were introduced in

\footnotetext{
${ }^{2}$ Nikolić (2008, pp. 3-4).

${ }^{3}$ Callender (2008, p. 1).

${ }^{4}$ Nikolić (2008); Burgan (2011).

${ }^{5}$ Callender (2008, p. 32).
} 
previous paragraphs and criticised by Callender. Instead, the paper will deal with two concepts of time, which were introduced by J. M. E. McTaggart, the A-series and the Bseries. ${ }^{6}$

The main argument of this paper is that, in fact, these are not two mutually incompatible concepts of time. On the contrary, these concepts could be translated ${ }^{7}$ into each other. This claim will be illustrated in two domains. Firstly, in the domain of temporal logic, where two types of system of logic, which simulate McTaggart's time series, are developed. Secondly, translatability will be presented for the case of natural language. Although the translatability in temporal logic, which was introduced by Prior, ${ }^{8}$ is not controversial, the latter translatability is often denied, primarily by presentists. ${ }^{9}$ However, their denial is, arguably, primarily based on their metaphysical views, and does not affect language.

Øhrstrøm and Hasle point out that temporal logic was implemented into computer science and Artificial Intelligence. ${ }^{10}$ Since systems of logic based on both the B-series and the A-series are used here, ${ }^{11}$ there is also a certain possibility of translatability in this field. This use of temporal logic in computer science and Artificial Intelligence is widely discussed among logicians and philosophers. ${ }^{12}$ Although the possibility of translatability of time series was not discussed in this field of study, it will be introduced in the last part of this paper, since it also affects significant issues, such as Artificial Intelligence and its naturalness.

\section{McTaggart and Two Series of Time}

The two time series, which will be crucial for further arguments, were postulated by John Ellis McTaggart in his paper 'The Unreality of Time'. ${ }^{13}$ McTaggart argued that time could be considered as the flow from past, to present and future. He entitled this concept of time as the A-series. In contrast to the former concept, time can also be

\footnotetext{
${ }^{6}$ McTaggart (1908).

${ }^{7}$ Apart from the verb 'translate' and the forms derived from it, I will use the verb 'transcribe' for a similar movement, which I intend to suggest. The verb 'translate' is better suited to the case of natural language, while the verb 'transcribe' applies better to logics.

${ }^{8}$ Prior (1967, pp. 38-41).

${ }^{9}$ See e.g. Smith (2002, pp. 3-4).

${ }^{10}$ Øhrstrøm \& Hasle (1995, pp. 344-365).

${ }^{11}$ Rodriguez and Anger (1996, pp. 89-90).

${ }^{12}$ See e.g. Øhrstrøm \& Hasle (1995, pp. 344-365); Copeland (2007); Müller \& Strobach (2012, p. 470).

${ }^{13}$ McTaggart (1908).
} 
understood as the relation between earlier and later moments. He called this concept the B-series. ${ }^{14}$

As follows from the title, McTaggart intended to prove the unreality of time. In order to establish his claim, McTaggart proposed an argument that the A-series is paradoxical. The argument explains a contradiction which is included in A-series:

1) The A-series is a series of change. ${ }^{15}$

2) The characteristics of past, present and future are mutually incompatible.

Every event has to possess one and only one of these characteristics. No more, no less.

3) In order to facilitate change, every event has to have all characteristics. ${ }^{16}$

This appears to be contradictory, but McTaggart admitted that the events could have these characteristics simultaneously. However, the explanation of this simultaneity contained a vicious circle. He argued that, in order to define simultaneity of change from past to present and from present to future, time had to be presumed. Since the Aseries is considered to be a representation of time, then the A-series has to be assumed in order to support postulation of the A-series. As a result, a vicious circle appears. Therefore, the A-series is either contradictory or it contains a vicious circle. ${ }^{17}$ From a logical point of view, none of the solutions is acceptable.

Moreover, McTaggart claimed that the B-series is dependent on the A-series, since change is possible only in the A-series and change is, according to McTaggart, an essential feature of time. McTaggart concluded that neither the A-series nor the B-series is an appropriate representation of time. In addition, he postulated an atemporal Cseries, which was not a series of change but a series of events' order, and which, according to him, represented the human notion of time. ${ }^{18}$

Criticisms of McTaggart's paradox appear in several papers. ${ }^{19}$ One of them, which will be important for further discussion, is presented here. C. D. Broad agreed

${ }^{14}$ Ibidem, p. 458.

${ }^{15}$ The position of events in B-series is permanent, according to McTaggart, and therefore if there is change in time, it must be in A-series. (McTaggart 1908, pp. 459-460).

${ }^{16}$ McTaggart claimed: "But every event has them all. If $\mathrm{M}$ is past, it has been present and future. If it is future, it will be present and past. If it is present, it has been future and will be past. Thus all the three incompatible terms are predicable of each event, which is obviously inconsistent with their being incompatible, and inconsistent with their producing change." (McTaggart 1908, p. 468).

${ }^{17}$ Ibidem, pp. 467-468.

${ }^{18}$ Ibidem, pp. 459-462, 473.

${ }^{19}$ See e.g. Havlík (1994) or Goldberg (2004). 
with McTaggart that pastness, presentness or futurity are mutually exclusive predicates. However, he argued that, while terms cannot have these predicates simultaneously or timelessly, they can have them successively. He claimed that there is no contradiction, and if there is no contradiction then the vicious circle, which was introduced to avoid the contradiction in McTaggart's argument, also need not arise. Broad maintained that McTaggart tacitly presumed that the meaning of sentence with a temporal copula had to be translatable into sentence with temporal predicates but without a temporal copula. This translation could be for instance the translation of ' $S$ is now $P$ ', where 'now' is a temporal copula, into 'There is a moment $t$, such that $S$ has $P$ at $t$ and $t$ is present.' Broad claimed that the copula 'is' is timeless in the second statement. It makes the copula to include simultaneously past, present and future, which lead into the contradiction pointed out by McTaggart. Therefore, according to Broad, McTaggart's paradox proves, rather, that there is no such translation, but not the unreality of time. ${ }^{20}$

Markosian argues that, in general, there are two reactions to McTaggart's argument, which would have not been approved by McTaggart. Firstly, philosophers questioned its adequacy. This approach is widespread among philosophers who favoured the A-series of time. Besides their criticism of McTaggart's paradox, proponents of the A-series would agree with McTaggart that the A-series is an essential description of time from which the B-series is derived.

Secondly, Markosian stresses that, even though McTaggart denied the reality of both time series, certain philosophers adopted just a part of his argument. They approved of McTaggart's argument for A-series contradiction, but they claimed that the $\mathrm{B}$-series is an appropriate representation of time. They argue that time lacks genuine Aseries properties but that it can be analysed with the properties of the B-series. Consequently, they deny that there is an absolute present from which past and future can be extracted, and assert that time does not flow. Apart from McTaggart's argument, the proponent of B-series could also deny the A-series on the basis of the special theory of relativity. ${ }^{21}$

Both approaches built up the distinction between the A-series and the B-series. The rest of the paper will focus on arguing that this distinction is not as sharp as seems to be. I will follow Williams' criticism of this distinction. He argues:

"The fact is that McTaggart's original characterizations of A- and B-time may not have delineated two clearly contrasting theories, each of which is believable. The fact is, too, that advocates of each theory believe that their own theory is self-evidently true and that the other theory is self-evidently

\footnotetext{
${ }^{20}$ Broad (1998, pp. 77-79).

${ }^{21}$ Markosian (2014).
} 
false. This second fact should alert us to the possibility that we have before us a false dichotomy." 22

Williams claim was criticised by Oaklander, ${ }^{23}$ Burley $^{24}$ and Deng ${ }^{25}$, however, their objections primarily apply to the metaphysical perspectives and the semantical analyses of sentences. They do not prove that there is a difference between the A-series and the B-series which could be perceived, as Deng admits:

"The contemporary analytic debates about time are [...] shaped by a disagreement about such matters as whether all times are ontologically on a par, whether monadic temporal properties exist, and whether there are any tensed facts, where these matters are stripped of the import they prima facie appear to have for the issue of dynamicity versus stasis." 26

\section{Temporal Logic}

Both time series introduced by McTaggart can be formalised in the systems of logic. Their formalisation in modern temporal logic was proposed by Arthur N. Prior. Prior independently introduced two ways of formalising temporality, ${ }^{27}$ which he later identified as A-series logic and B-series logic. ${ }^{28}$ In addition, Prior also proposed a transcription of one such system of logic into the other and, thus, the unification of these systems of logic into one system. ${ }^{29}$ Blackburn considers this unified system to be a precursor of modern hybrid logic. ${ }^{30}$

Prior dealt with temporality and future contingence, even before the introduction of his temporal operators, in the paper 'Three-Valued Logic and Future Contingents', where he discussed Łukasiewicz's many-valued logic. ${ }^{31}$ His temporal logic was introduced in the paper 'Diodoran Modalities', where he postulated four temporal operators:

\footnotetext{
${ }^{22}$ Williams (1996, p. 381).

${ }^{23}$ Oaklander (2001).

${ }^{24}$ Burley (2007).

${ }^{25}$ Deng (2010).

${ }^{26}$ Ibidem, p. 752.

${ }^{27}$ Prior (1955, pp. 205-206, 211; 1962, p. 36).

${ }^{28}$ Prior (1967, pp. 38-45).

${ }^{29}$ Ibid. (1967, pp. 38-41 and 88-92).

${ }^{30}$ Blackburn (2006, p. 368).

${ }^{31}$ Prior (1953).
} 
'Fp' - 'it will be the case that $p$ '

'Gp' - 'it will always be the case that $p$ '

'Pp' - 'it has been the case that $p$ '

'Hp' - 'it has always been the case that $p$ '

while:

$$
\begin{aligned}
& \mathrm{Gp} \equiv \neg \mathrm{F} \neg \mathrm{p} \\
& \mathrm{Hp} \equiv \neg \mathrm{P} \neg \mathrm{p}^{32}
\end{aligned}
$$

There are several systems of logic which contain these operators and, hence, these are A-series systems. However, the basic system is $\mathrm{K}_{\mathrm{t}}$, for which the axioms are:

$1, \mathrm{p}$, where $\mathrm{p}$ is a tautology of the propositional calculus

$$
\begin{aligned}
& 2, \mathrm{G}(\mathrm{p} \rightarrow \mathrm{q}) \rightarrow(\mathrm{Gp} \rightarrow \mathrm{Gq}) \\
& 3, \mathrm{H}(\mathrm{p} \rightarrow \mathrm{q}) \rightarrow(\mathrm{Hp} \rightarrow \mathrm{Hq}) \\
& 4, \mathrm{p} \rightarrow \mathrm{HFp} \\
& 5, \mathrm{p} \rightarrow \mathrm{GPp}
\end{aligned}
$$

And the rules are:

RMP: If $F \mathrm{p}$ and $\mathrm{p} \rightarrow \mathrm{q}$, then $F \mathrm{q}$.

RG: If $-p$, then Gp

RH: If $F$, then $\mathrm{Hp}^{33}$

The U-calculus can be seen as a representation of the B-series system of logic in Prior's work. The fundamental operator of the system is ' $U$ ', where ' $U(a b)$ ' means ' $a$ ' is earlier than ' $b$ ' or 'jump from possible world ' $a$ ' to possible world ' $b$ '" with regard to interpretation. The system was invented by Prior and Carew A. Meredith in 1956, ${ }^{34}$ but the paper remained unpublished until $1996 .{ }^{35}$ Prior discussed this system of logic in his paper 'Possible Worlds', where he interpreted it as a system of modal logic. ${ }^{36}$ However, Prior claimed that possible worlds and time instants are similar entities and used the system as both a modal and a temporal system of logic. ${ }^{37}$ Later, Prior also added the

\footnotetext{
${ }^{32}$ Prior $(1955,205-206$, p. 211).

${ }^{33}$ See Øhrstrøm and Hasle (1995, pp. 373-374).

${ }^{34}$ Prior \& Meredith (1996, pp. 133-134).

${ }^{35}$ See Copeland (2006, pp. 378-379).

${ }^{36}$ Prior (1962).

${ }^{37}$ Prior (1967, pp. 188-189).
} 
operator ' $\mathrm{Y}$ ' to the U-calculus, where ' $\mathrm{Y}(\mathrm{ab})$ ' means ' $\mathrm{a}$ ' is later than ' $\mathrm{b}$ ', and consequently:

$$
\mathrm{U}(\mathrm{ab}) \equiv \mathrm{Y}(\mathrm{ba})^{38}
$$

Variables of the system stand for possible worlds or time instants. ${ }^{39}$ In addition, Jakobsen points out that B-logic did not need temporal operators and that it used quantifiers instead. ${ }^{40}$

Although, Prior was aware of the fact that the A-series differs from the B-series, he pointed out that A-series logics and B-series logics are mutually translatable. He argued:

"It is important, as we have seen, not to treat the A series as if it were a B series; just that constitutes McTaggart's Fallacy. It was, however, practically his only fallacy in this area, and it should not lead us to imagine that the A series and the $\mathrm{B}$ series are so distinct that they cannot be brought into a common context. As McTaggart said, the A series 'slides along' the B series and vice versa; 'later and later terms pass into the present' and 'presentness passes to later and later terms'."41

Prior pointed out that the B-series is not a tenseless series as it is often interpreted, but that it is tensed similarly to the A-series. He claimed that disjunction of certain dated propositions could be true in all times but this does not mean that the dated propositions themselves are atemporal. For example, Prior drew a distinction between two meanings of truths-true in all times and true atemporally. ${ }^{42}$ The latter interpretation could cause McTaggart's paradox but Prior claimed that it applies neither to the A-series nor to the B-series. Therefore, Prior concluded that B-series propositions did not contain the tenseless 'is', which, according to Broad, caused McTaggart paradox. Consequently, McTaggart's paradox is avoided and the translation between A-series logics and Bseries logics is possible. ${ }^{43}$

The translation between two calculi was defined as:

$$
\mathrm{T}(\mathrm{pq}) \equiv \square(\mathrm{p} \rightarrow \mathrm{q})
$$

\footnotetext{
${ }^{38}$ Ibidem, p. 183.

${ }^{39}$ I order to allow the translation from A-series logic to B-series logic, Prior (1967, p. 89) argued that world's variable and instant's variable should be treated as propositional variables.

${ }^{40}$ Jakobsen (2013, p. 94).

${ }^{41}$ Prior (1967, p. 101).

${ }^{42}$ A similar distinction could be found also in Rescher`s (1966, pp. 75-76) paper, which influenced Prior, as will be mentioned further.

${ }^{43}$ Prior (1967, pp. 101-102).
} 


$$
\mathrm{U}(\mathrm{pq}) \equiv \square(\mathrm{q} \rightarrow \mathrm{Pp}) \quad(\equiv \mathrm{T}(\mathrm{qPp}))^{44}
$$

where 'T(pq)' means 'In the state of affairs in which 'p', it is the case that 'q'. 45

This step by Prior was inspired by Nicholas Rescher, who had previously proposed a certain unification of these two types of logic:

"The interactions between the A series and the B series which emerge from Rescher's paper may be summed up as follows: If we use the form Tap to mean 'It is the case at the date $a$ that $p$ ' its laws are very similar to those of the Fnp of our simplest interval-calculus, the one in which Pnp is defined as $F(-n) p . " 46$

Prior proved, further, that formulas from various A-series logics could be translated into U-calculus, and vice versa. He used this outcome in proofs of further theorems of these systems of logic. ${ }^{47}$ However, he neither proved nor intended to prove that every formula of any A-series logic is translatable into any system of B-series logic. ${ }^{48} \mathrm{He}$, rather, demonstrated that the translation between these two systems is possible and that it did not cause McTaggart's paradox.

In spite of the possibility of translation expressed above, Prior stressed that the Aseries is prior and that the B-series is definable in terms of it, but not vice versa. He argued:

"This gives us all we need for moving freely in and out of $U$-calculi from the tense-logics to which they correspond. We can also see more clearly the sense in which the B series is definable in terms of the A series but not vice versa. The tensed $p$ can only enter the B-series logic as part of the form Tap (which, however, is itself tense-logically definable); the B-series logic has no counterpart of the simple tensed $p . " 49$

${ }^{44}$ Ibidem, p. 89.

${ }^{45}$ See Prior (2003, p. 252).

${ }^{46}$ Prior (1967, p. 103).

${ }^{47}$ Ibidem, pp. 90-111, 179-180.

${ }^{48}$ In fact, Prior claimed that not every formula of B-logic is translatable into A-logic (1967, p. 198): “...L is not only not defined in a particular calculus but is undefinable in tense-logical terms, is a move that would have profound effects both philosophically and formally. It would mean that we cannot reduce the U-calculus (the logic of the B series) wholly to tense-logic (the logic of the A series) after all; and this could be regarded as advantageous or disadvantageous, according to our point of view."

${ }^{49}$ Prior (1967, p. 197). 
This prioritising of A-series logics might have been caused by the fact that Prior had certain ontological objections to B-series logics. ${ }^{50}$ Besides these ontological disadvantages, U-calculus has a greater expressive power. Hence, Prior had to advocate his preference of A-series logic. As Blackburn demonstrates, in order to prove priority of A-series logic, Prior 'hybridised' his system of logic. ${ }^{51}$

Hybrid logic could serve as another example of the translatability of the two concepts of time, since it unifies A-series and B-series logics. Namely, as Blackburn shows, two types of quantifiers are used here, temporal quantifiers ' $\mathrm{P}$ ' and ' $\mathrm{F}$ ' and classical quantifiers ' $\forall$ ' and ' $\exists$ '. In addition, it uses a special quantifier, 'Q', which creates a nominal from the propositional variable. 'Qp' means that ' $p$ ' is true at precisely one point. Prior's hybrid logic contains the notion of past, present and future due to the temporal quantifiers, and identifies specific points (or time instants) at the same time due to the quantifier ' $Q$ '. The former feature is a part of the A-series concept of time, while the latter belongs to the B-series concept of time. ${ }^{52}$

Blackburn stressed that Prior's hybridisation might have been overly applicable. Prior's approach could not only be applied to temporal logic but also to his egocentric logic and to any system which is described from the internal point of view. Since it is not a unique procedure, the hybridisation does not provide a proof that A-series logics are prior to B-series logics. ${ }^{53}$ Consequently, Prior's reason for hybridising temporal logic failed. Despite this, it does not affect the fact that hybrid logic unifies certain features of A-series and B-series logics.

\section{Natural Language}

The translation of the two logics is not trivial and based on common sense. On the contrary, according to a common sense view of language, there should be no difficulties in translating talk which belongs to the A-series to talk of the B-series. ${ }^{54}$ Moreover, a similar replacement to that which was suggested by Prior in the case of logic was suggested by S. S. C. Smart ${ }^{55}$ for the case of natural language. He claimed that 'is past'

\footnotetext{
${ }^{50}$ Ibid (1967, pp. 189-190).

${ }^{51}$ Blackburn (2006, pp. 353-360).

52 Ibidem, pp. 353-354.

${ }^{53}$ Ibidem, pp. 362, 364, 367.

${ }^{54}$ For instance, Joseph (2009, pp. 366-372) identifies no significant linguistic difference between A-series and B-series. However, he does not take into account the lasting discussion which will be presented in this chapter.

${ }^{55} \mathrm{He}$ was actually, Prior's friend and they discussed this issue a great deal. (see e.g. Jakobsen 2013, pp. 35-38)
} 
could be translated as 'it was earlier than this utterance', 'is present' as 'it is simultaneously with this utterance' and 'is future' as 'is later than this utterance'. His main aim was, in contrast with Prior, to demonstrate the priority of the B-series. ${ }^{56}$ However, he did not exclude the translation from B-series to A-series statements. Thus, his objections to the A-series arose from his metaphysical point of view.

It appears, however, that metaphysical and semantical issues in these cases are so robust that the protagonists of both sides argue that translation is not possible without loss of meaning. Claims of this kind are supported by proponents of A-series ${ }^{57}$ and, similarly, by proponents of B-series ${ }^{58}$ who argue for a new tenseless theory of time. There are, however, philosophers ${ }^{59}$ who claim that postulating this difference between sentences just leads to the misinterpretation of the A-series and B-series of time. In this chapter I will present the argument of Quentin Smith, who argues that the difference between A-series and B-series claims is significant.

In natural language, both time series can be expressed. Besides, McTaggart also formulated his paradox in natural language. Nonetheless, Smith points out that proponents of the A-series understand the semantics of certain sentences differently. There is, according to them, a difference between tensed and tenseless statements. In particular, there is a difference in the meaning of 'now' in the following sentence:

It is snowing now.

This, according to certain proponents of the A-series, implies that the 'snowing' has the property of presentness, while the proponents of the B-series maintain that 'now' in the sentence refers to the date of reference, e.g. to $11^{\text {th }}$ November 2016. Consequently, the former theory differs from standard philosophy of language. ${ }^{60}$ Oaklander argues that the proponents of the B-series understand the sentence in a Fregean way, i.e. every sentence 'It is snowing' is a unique statement about the state of the world with its unique truthvalue. ${ }^{61}$ In contrast, certain proponents of A-series, such as Prior, understand the sentence in the medieval way, i.e. that it could be uttered several times and its truthvalue could change. ${ }^{62}$

\footnotetext{
${ }^{56}$ Smart (1949, pp. 492-493).

${ }^{57}$ See e.g. Smith (2002, pp. 3-4).

${ }^{58}$ See e.g. Oaklander (1998, p. 188).

${ }^{59}$ See e.g. Williams (1996, p. 379).

${ }^{60}$ Smith (2002, v).

${ }^{61}$ Oaklander (1998, p. 188).

${ }^{62}$ Prior (2003, p. 213).
} 
It is not possible to present all of Smith's examples here, however, the following example provides an adequate demonstration of Smith's solution. Smith shows the untranslatability of the A-statement and B-statements for the following example of the A-statement:

(1) It was true that the era devoid of linguistic utterances is present. ${ }^{63}$

He claims that none of proposed B-statements could translate it correctly. He suggests:

(1A) It (is) true, earlier than this utterance, that the era devoid of utterances

(is) simultaneous with this utterance. ${ }^{64}$

Smith argues that the first statement could be true or false in respect to a situation, but that the second is contradictory. Consequently, the statement (1) is not a correct translation of the statement $(1 \mathrm{~A}) .{ }^{65}$

Smith's example is not completely fair. Statement (1) mixes language with metalanguage, and there is also trouble with self-reference. It contains features of metalanguage since it ascribes a truth-value. The issue of self-reference is caused by the passage 'the era devoid of utterances'. Specifically, Smith postulated three conditions, which are according to him contained in the first statement:

a. There (is) an era devoid of utterances earlier than the utterance of (1).

b. There (is) some utterance-independent truth vehicle $\mathrm{V}$ that is expressed

by the clause prefixed by "It was true that."

c. V (is) true during the era devoid of utterances. ${ }^{66}$

In condition ' $b$ ', where Smith postulated 'some utterance-independent truth vehicle', he expresses that it is not a case that depends on language anymore. This phrase belongs, more likely, to meta-language. The idea that ' $\mathrm{V}$ ' is a part of the meta-language is also implicitly contained in condition ' $c$ '. In addition, condition ' $a$ ' includes the problem of self-reference. Consequently, the translation of the A-series part of the statement is not the most challenging part of the work. The initial statement is already filled with more serious obstacles.

They could be overcome, however, but not by Smith's translation. At first, Prior, in accordance with Ramsey, ${ }^{67}$ points out that the claim 'is true' could be eliminated as

\footnotetext{
${ }^{63}$ Smith (2002, p. 73).

${ }^{64}$ Ibidem, p. 74.

${ }^{65}$ Ibidem, pp. 73-78.

${ }^{66}$ Ibidem, p. 73.

${ }^{67}$ Ramsey (1965, pp. 143-155).
} 
superfluous, since it is just an expression of what is the case. ${ }^{68}$ Thus, statement (1) will look like:

(1*) The era devoid of all utterances was present.

and its translation to the B-statement as:

$\left(1 \mathrm{~A}^{*}\right)$ Earlier than this utterance, the era devoid of all utterances (is) the case.

This escape might have been too easy. There is, however, another possible analysis. If the statement of truth and the indication of present are considered as important parts of the statement, the logical analysis of it could be beneficial. Statement (1) could also be translated as:

(1A') Earlier than this utterance, it (is) true that the era devoid of linguistic utterances is the case at that moment.

Although statement (1 $\left.\mathrm{A}^{\prime}\right)$ also contains meta-language and self-reference, it is not contradictory. Additionally, it fulfils the condition ' $a$ ', which is not fulfilled by statement (1A). The reason why Smith uses the contradictory (1A), instead of (1A'), is the fact that he uses the precise replacement of A-series' variables that were suggested by proponents of B-series. ${ }^{69}$ The solution here is inspired by Prior, who was a proponent of A-series.

As a result, statement (1) can be transcribed into logic, with a little help from condition ' $a$ ', which allows introducing the proposition as:

$$
\square(\mathrm{P}(\mathrm{NV} \wedge \mathrm{Np}) \rightarrow \mathrm{q})
$$

where the variable ' $N$ ' stands for 'is present'. This formula could be transcribed according to rules mentioned in the previous chapter as

$$
\mathrm{Y}((\mathrm{aV} \wedge \mathrm{ap}) \mathrm{q})
$$

and transformed into:

$$
\mathrm{U}(\mathrm{q}(\mathrm{aV} \wedge \mathrm{ap}))
$$

which corresponds with statement (1A') (where the variable ' $a$ ' stands for a time instant).

Statement (1A') is definitely more complicated and less clear than statement (1). In ordinary communication, statement (1) would be preferable. However, the argument

\footnotetext{
${ }^{68}$ Prior (1971, pp. 11-13).

${ }^{69}$ Smith (2002, pp. 73-74).
} 
was directed at the obstacles to translatability, which just stresses the gap between Aseries and B-series. This gap seems to be merely artificial.

\section{Computer Science and Artificial Intelligence}

Øhrstrøm and Hasle claim that the usefulness of temporal logic in computer science was already recognised in the 70s by Amir Pnueli. Although Pnueli did not use Prior's temporal logic, instead utilising Rescher's system of logic, he later also discovered Prior. ${ }^{70} \varnothing \mathrm{hrstr} \varnothing \mathrm{m}$ and Hasle stress that computer scientists have to choose between Aseries and B-series systems of logic, and that, in computer science, B-series logics tend to be preferred. ${ }^{71}$ They argue, however, that A-series logic or hybrid logic could be also relevant, for example, for the case of 'The Tower of Hanoi' query. ${ }^{72}$ Additionally, Rodriguez and Anger conclude that the situation in computer science is even more complicated than the easy division between A-series and B-series systems of logic. They argue:

"If there is one word which sums up the current concern with time in computer science, it is diversity.",73

Rodriguez and Anger point out that there are several parts of computer science where temporal logic has been usefully applied. Firstly, temporal logic was used in programs that provide reasoning about concurrent programs. These programs allow for expressing different possible outputs of operation and, consequently, different executions of them. Secondly, real time systems also benefit from the use of temporal logic. Most of these systems deal with asynchronous events in non-deterministic order, which must be solved promptly. However, the most distinctive feature of real-time systems is fairness in the ordering of different activities. Thirdly, another occasion for the use temporal logic in computer science is in planning. In contrast to real-time systems, planning systems are more complex and slow. Fourthly, temporal logic is relevant for databases. Apart from the processes which run simultaneously, databases have to differentiate current from possible values. In addition, time-information is also stored in databases, hence, it is also important to distinguish between period- and date- related information. Fifthly, temporal logic could be valuable in the automated checking of system

\footnotetext{
${ }^{70}$ Øhrstrøm \& Hasle (1995, p. 344).

${ }^{71}$ Ibidem, p. 347.

${ }^{72}$ Ibidem, pp. 348-355.

${ }^{73}$ Rodriguez \& Anger (1996, pp. 90-91).
} 
specifications. It primarily applies to specifications linked with time, for instance the dynamic consistency of the system. ${ }^{74}$

Finally, Rodriguez and Anger stress that another use of temporal logic has been suggested by those developing the knowledge base of Artificial Intelligence. In order to behave intelligently, a system has to make decisions based on the information that it includes. Additionally, the system's outputs have to be in the correct order, and the ordering of information, rules or outputs is the part where temporal logic could be useful. However, there is no consensus as to whether A-series or B-series logic should be preferred. ${ }^{75}$ Allan favoured an instant-based system of logic, which resembles the Aseries or, rather, Prior's hybrid logic, since variables from U-calculus are also used. ${ }^{76}$ On the contrary, other researchers prefer point-based systems of logic. ${ }^{77}$

In the discussions about the naturalness of Artificial Intelligence, the concept of time in which each system is embedded is of considerable potential relevance. While Aseries systems resemble the human understanding of time, widely used B-series systems are closer to the scientific model of it, as was stated previously. However, if there is a possibility of translatability, as in temporal logic and natural language, then even Bseries systems of logic could be considered to be 'natural'. There are some hints of translatability in the hybridised systems, such as Allen's, ${ }^{78}$ but translation from B-series systems to A-series systems is needed. Unfortunately, this approach has not yet been extensively discussed.

\section{Conclusion}

Taking everything into account, there is a tension between two concepts of time, the Aseries, which describes time as a flow from past to present and future, and the B-series, which considers time as a static relation between earlier and later moments. Besides this tension, the division which was built between these two theories is, arguably, artificial. There could be a translation between the two concepts and the differences between them may just be metaphysical.

From the philosophical point of view, both concepts prove their usefulness in logic, natural languages and computer science. Regardless of the real nature of time, this suggests that both of them are worth having and that, consequently, neither should be

\footnotetext{
${ }^{74}$ Ibidem, pp. 91-97; 99-104.

${ }^{75}$ Ibidem, pp. 97-99.

${ }^{76}$ Allan (1984).

${ }^{77}$ See Rodriguez \& Anger (1996, pp. 98-99).

${ }^{78}$ Allan (1984).
} 
rejected. This claim could be further strengthened by suggestions of possible translatability in computer science and in the systems on which Artificial Intelligence are based. This could also provide an answer regarding some issues linked with Artificial Intelligence.

\section{Bibliography}

Allen, J. F. (1984): “Towards a General Theory of Action and Time.” Artificial Intelligence 23: 123-154.

Blackburn, P. (2006): “Arthur Prior and Hybrid Logic.” Synthese 150: 329-372.

Broad, C. D. (1998): "McTaggart's Argument against the Reality of Time: an Excerpt from Examination of McTaggart's Philosophy.” In Metaphysics the Big Questions, eds. P. Van Inwagen \& D. Zimmerman, Blackwell Publishers, Oxford, 1998, pp. 74-79.

Burgan, R. (2011): “Existuje vôbec jediná časová línia tiahnuca sa priamo až k vel’kému tresku?" E-logos 5: 1-37.

Burley, M. (2007): "Beyond "Beyond A- and B-time"." Philosophia 34: 411-416.

Callender, C. (2008): “Time's Ontic Voltage” [online]. Available at: <http://philosophyfaculty.ucsd.edu/faculty/ccallender/Time'sOnticVoltage.pdf.>.

Copeland, B. J. (2006): "Meredith, Prior and the History of Possible Worlds Semantics." Synthese 150: 373-397.

Copeland, B. J. (2008): “Arthur Prior.” In The Stanford Encyclopedia of Philosophy [online]. ed. E. N. Zalta, Available at: <http://plato.stanford.edu/archives/fall2008/entries/prior/>.

Deng, N. (2010): “'Beyond A- and B-Time’ Reconsidered.” Philosophia 38: 741-753.

Goldberg, N. (2004): “McTaggart on Time.” Logic and Logical Philosophy 13: 71-76.

Havlík, V. (1994): "K analýze McTaggartova paradoxu: Paradox McTaggartova paradoxu." Filosofický časopis 42: 76-87.

Jakobsen, D. (2013): “Arthur Norman Priors bidrag til metafysikken.” PhD diss., Aalborg University.

Joseph, J. (2009): “Existuje minulost?” Organon F 16: 363-380.

Markosian, N. (2014): “Time." In The Stanford Encyclopedia of Philosophy [online], ed. E. N. Zalta, Available at: <http://plato.stanford.edu/archives/spr2014/entries/time/>.

McTaggart, J. M. E. (1908): “The Unreality of Time.” Mind 17: 457-474.

Müller, T. \& Strobach, N. (2012): "A Letter on the Present State of Affairs: Prior, Indeterminism and Relativity 40 Years Later." Synthese 188: 469-485. 
Nikolić, H. (2008): “Block time: Why Many Physicists Still Don’t Accept It?” [online]. Available at: <http://citeseerx.ist.psu.edu/viewdoc/download?doi=10.1.1.424.7985\&rep=rep $1 \&$ type $=$ pdf $>$.

Oaklander, L. N. (1998): "Freedom and the New Theory of Time." In: Questions of Time and Tense, ed. R. Le Poidevin, Clarendon Press, Oxford, 1998, pp. 185-205.

Oaklander, L. N. (2001): "Is there a Difference between the Metaphysics of A-time and B-time?" Journal of Philosophical Research 26: 23-36.

Øhrstrøm, P. \& Hasle, P. V. F. (1995): Temporal Logic: From Ancient Ideas to Artificial Intelligence. Kluwer Academic Publisher, Dodrecht, 1995.

Prior, A. N. (1953): “Three-Valued Logic and Future Contingents." Philosophical Quarterly 3: 317-26.

Prior, A. N. (1955): “Diodoran Modalities.” Philosophical Quarterly 5: 205-213.

Prior, A. N. (1957): Time and Modality. Clarendon Press, Oxford.

Prior, A. N. (1962): “Possible Worlds.” Philosophical Quarterly 46 (1962): 36-43.

Prior, A. N. (1967): Past, Present and Future. Clarendon Press, Oxford.

Prior, A. N. (1971): Object of Thought. Clarendon Press, Oxford.

Prior, A. N. \& Meredith, C. A. (1996): "Interpretations of Different Modal Logics in the "Property Calculus"." In Logic and Reality: Essays on the Legacy of Arthur Prior, ed. B. J. Copeland, Clarendon Press, Oxford, 1997, pp. 133-134.

Prior, A. N. (2003): Papers on Time and Tense. Eds. P. Hasle, P. Øhrstrøm, T. Braüner \& J. Copeland, Oxford University Press, Oxford.

Ramsey, F. P. (1965): The Foundation of Mathematics and Other Logical Essays. Ed. R. B. Braithwaite, Routledge, London.

Rescher, N. (1966): “On the Logic of Chronological Propositions.” Mind 75: 75-96.

Rodriguez, R. \& Anger, F. (1996): "Prior's Temporal Legacy.” In Logic and Reality: Essays on the Legacy of Arthur Prior, ed. B. J. Copeland, Clarendon Press, Oxford, 1996, pp. 89-109.

Smith, Q. (2002): Language and Time. Oxford University Press, New York.

Smart, S. S. C. (1949): “The River of Time.” Mind 58: 483-494.

Williams, C. (1996): “The Metaphysics of A- and B-Time." Philosophical Quarterly 46: $371-81$. 